\title{
SPECIES OF THE GENUS GAURAX OF THE EASTERN UNITED STATES.
}

\author{
By Charles W. Johnson, \\ Boston Society of Natural History.
}

These interesting little flies are only occasionally taken in sweeping but can often be obtained in some numbers in breeding other insects, as they differ from other members of the family Oscinidæ, in feeding upon insect remains instead of vegetable matter. They are not parasitic but inquilinous or more properly speaking scavengers, the larvæ feeding upon the cast-off skins of caterpillars, pupæ cases and spider eggs.

Gaurax anchora Loew has been bred from the cocoons, etc., of Samia cecropia, Hemerocampa leucostigma (Tussock moth); Porthetria dispar (Gypsy moth), and egg cluster of Corydalis cornutus. Gaurax aranea Coq., of California was reared from the egg-sac of a spider (Argiope riparia), and Gaurax lancifer Coq. of the West Indies, also from egg-sacs of spiders. The habits of the other species are unknown. The Gaurax ephippium Zett., referred doubtfully to this genus by Coquillett in the list of Diptera of Beulah, New Mexico, (Trans. Amer. Ent. Soc., XXIX, 106, 1903) is a Chlorops according to European authors.

In studying the New England species collected during the past few years, I find one new species, making four from this region. They may be tabulated as follows:-

1 Thorax yellow, with a black dorsal mark ...................

Thorax entirely black; scutellum yellow...............montanus Coq.

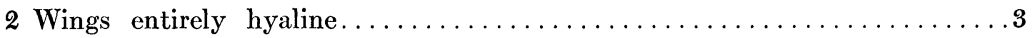

Wings with the basal half smoky black............ obscuripennis sp. n.

3 Thorax with a narrow anchor-shaped mark; scutellum also marked with

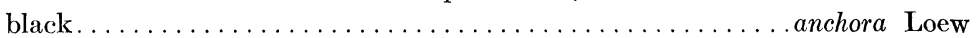

Thorax with a broad mark, the posterior edge tridentate; scutellum entirely yellow festiva Loew

Gaurax montanus Coquillett.

Aside from the type locality, White Mountains, N. H., I have collected this species at Norwich, Vt., July 8, 1908. 
Gaurax obscuripennis sp. nov.

Face black, front brown, vertex yellow, ocellar triangle and occiput black; basal joints of the antennæ yellowish, third joint black, aristæ whitish, densely pilose. Thorax yellow, with whitish hairs and a dorsa lline, broad in front and becoming gradually narrower posteriorly, humerus, a small spot in front of the wing, and a large spot on the center of the pleura, black, the metanotum yellow, with a black spool-shaped mark. Abdomen black. Halteres black, stems light yellow. Legs light yellow, the apical third of the posterior femora black. Wings smoky, the basal half forward of the fifth longitudinal vein blackish. Length, $1.5 \mathrm{~mm}$.

One specimen, Chester, Mass., August 7, 1912. Type in the collection of the Boston Society of Natural History.

\section{Gaurax anchora Loew.}

Elachiptera dispar Williston, in Furbush and Fernald, Rept. on Gypsy Moth, 1896, p. 390 , pl. 53, fig. 12.

Collected by the writer at Weston, Mass., July 23, 1911.

Gaurax festivus Loen.

Beverly, Mass., July 20, [Burgess] (U. S. Nat. Mus.); Auburndale, Mass., June 12; Pottstown, Pa., August 8, (C. W. Johnson).

In addition to the above the following species was discovered among some unidentified material.

\section{Gaurax pseudostigma sp. nov.}

o Face, front and antennæ yellow, ocelli and occiput black. Thorax and scutellum yellow, with whitish hairs, metathorax shining, yellow, with a narrow band of black below the scutellum. Atdomen yellow, with broad bands of black on the posterior portion of the segments, the first narrowly interrupted. Halteres and legs light yellow. Wings hyaline, with a black stigma-like spot at the end of the marginal cells. Length, $1.5 \mathrm{~mm}$.

One specimen, Toronto, Ontario, Canada, July 4, 1911 (M. C. Van Duzee). 

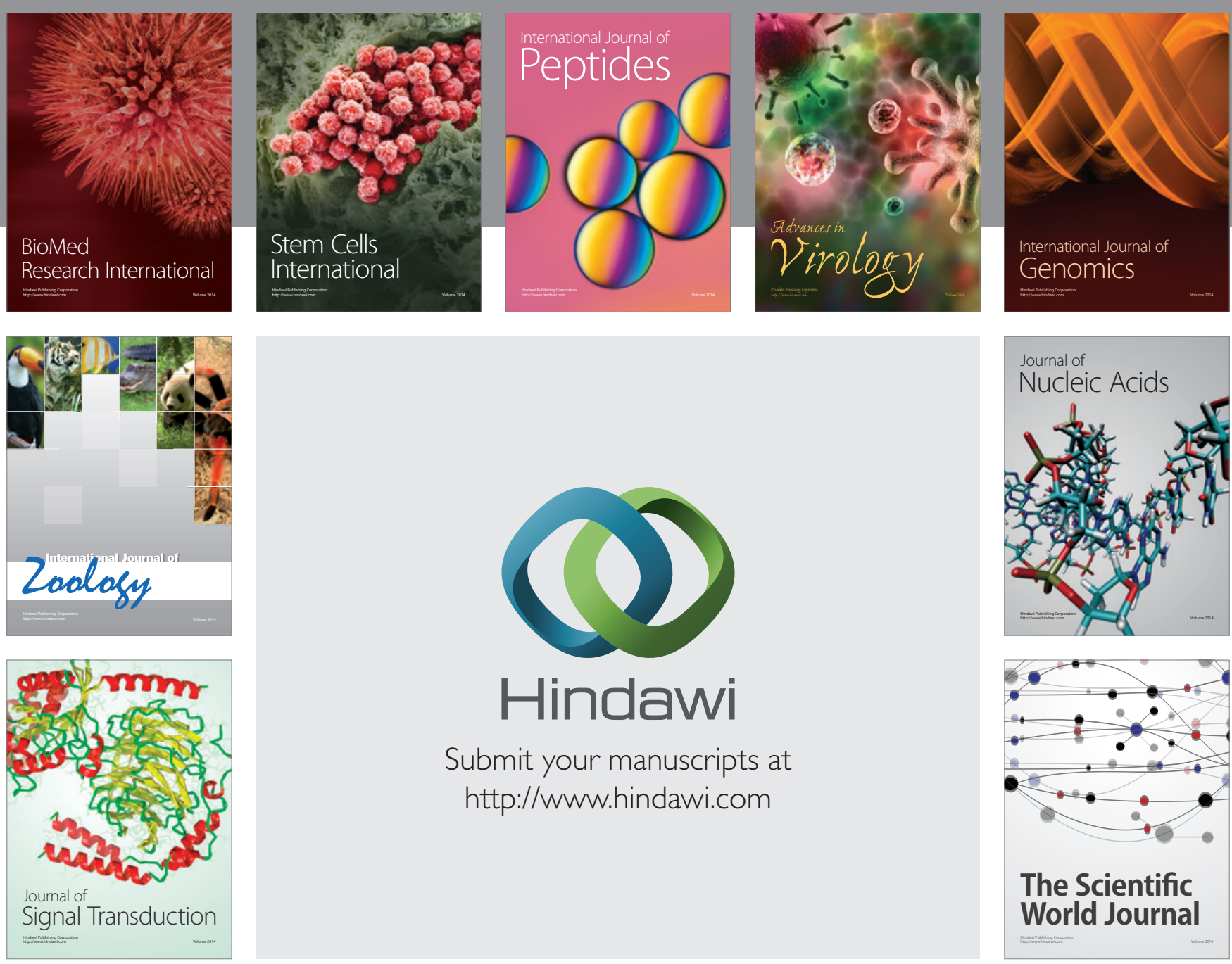

Submit your manuscripts at

http://www.hindawi.com
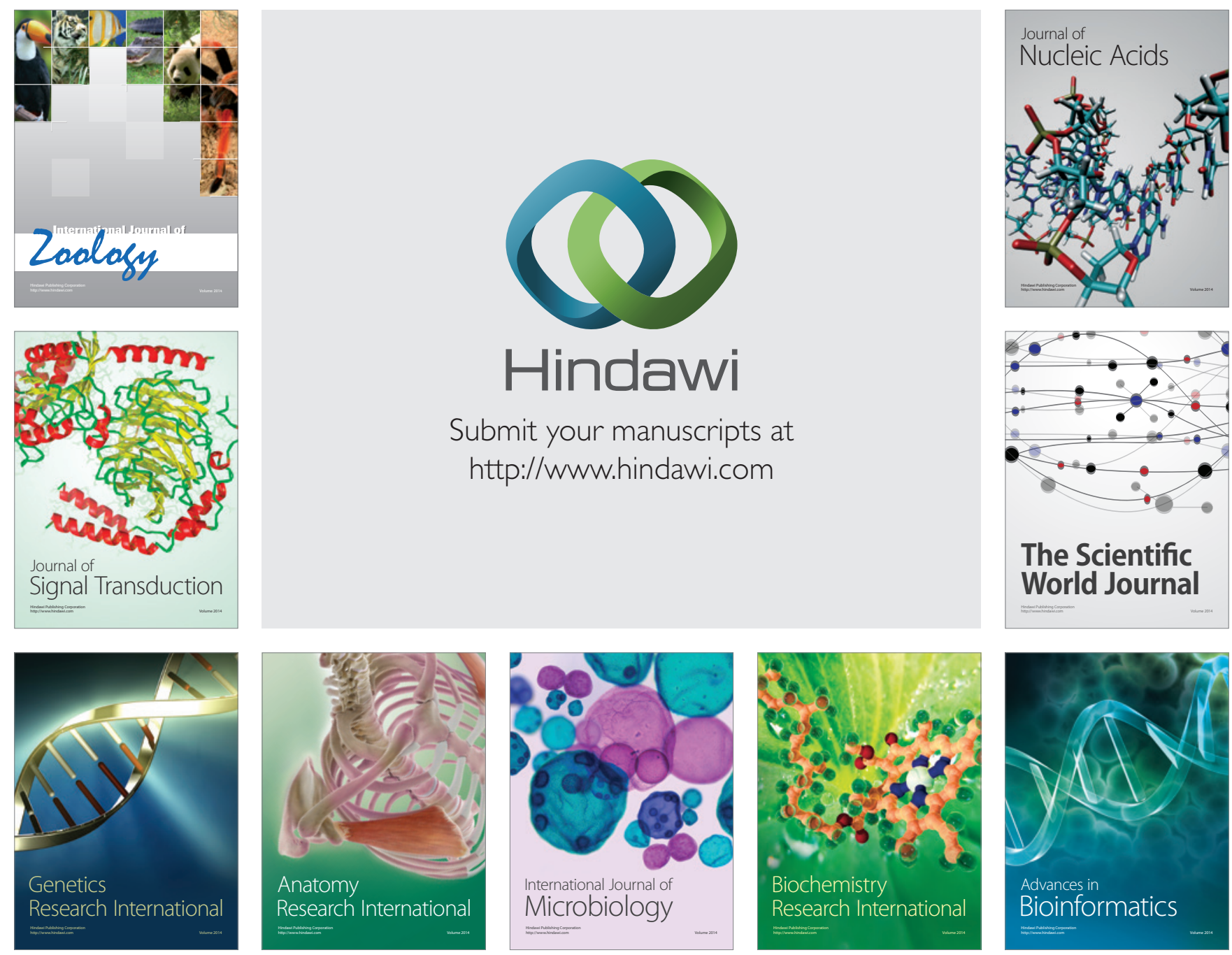

The Scientific World Journal
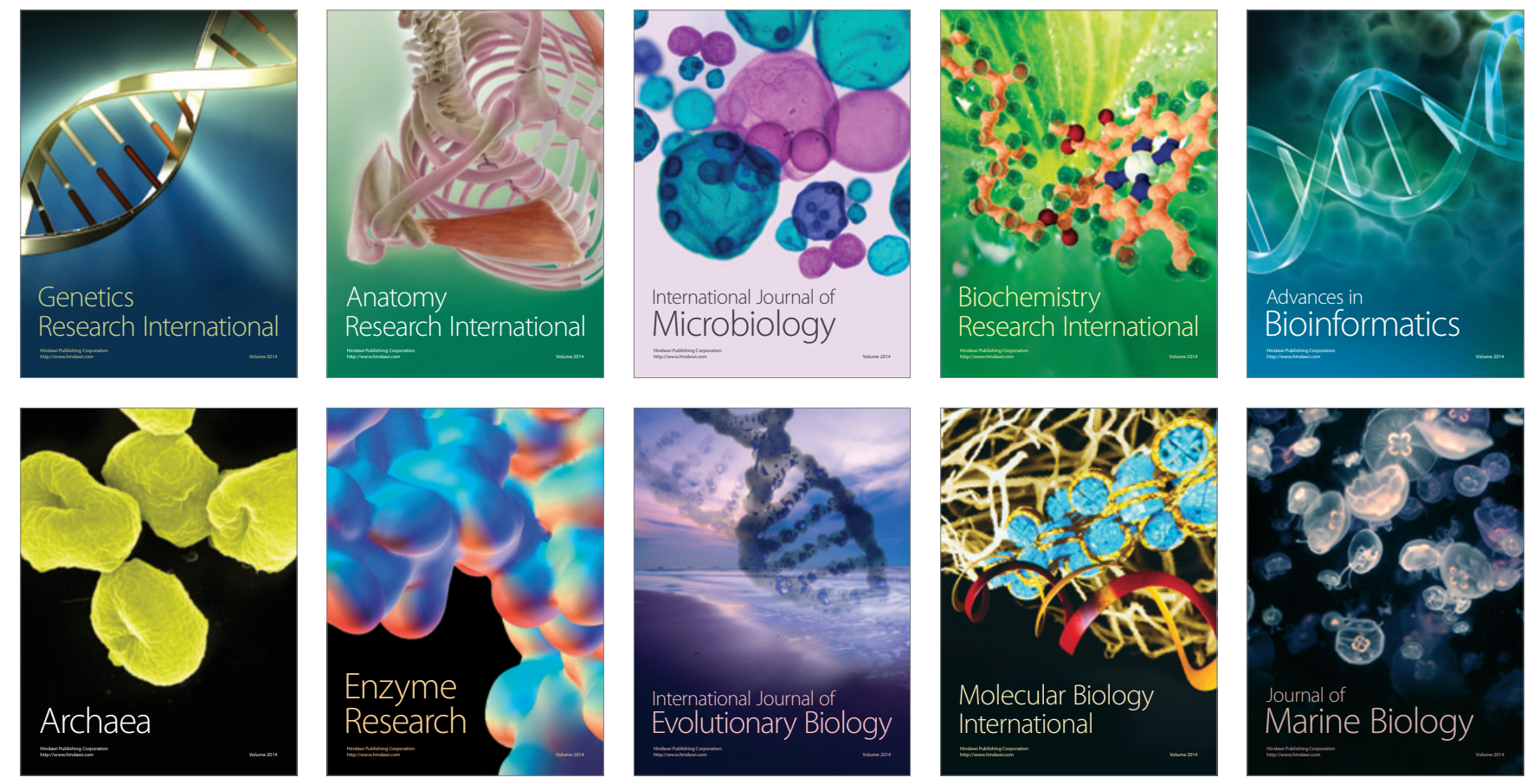